\title{
Pengaruh Konsentrasi Pupuk Walne Terhadap Laju Pertumbuhan dan Kandungan Klorofil-a Tetraselmis chuii
}

\author{
Nevanda Kusuma Wardani, Endang Supriyantini*, Gunawan Widi Santosa \\ Departemen IImu Kelautan, Fakultas Perikanan dan IImu Kelautan, Universitas Diponegoro \\ Jl. Prof.H.Soedarto S.H, Tembalang,Semarang, Jawa Tengah 50275 Indonesia \\ *Corresponding author, e-mail : supri_yantini@yahoo.com
}

\begin{abstract}
ABSTRAK: Walne merupakan media sintetis yang sering digunakan sebagai media kultur mikroalgae. Pupuk Walne sudah cukup memenuhi kebutuhan nutrien bagi mikroalgae kultur jika dibandingkan denga pupuk organik. Penelitian ini bertujuan untuk mengetahui laju pertumbuhan dan kandungan klorofil-a mikroalga Tetraselmis chuii pada kultur dengan perbedaan konsentrasi pupuk Walne. Materi yang digunakan adalah mikroalga Tetraselmis chuii dan pupuk Walne yang diperoleh dari Balai Besar Pengembangan Budidaya Air Payau (BBPBAP) Jepara. Metode penelitian ini adalah percobaan di laboratorium (experimental laboratory). Perlakuan yang diberikan adalah dengan pemberian konsentrasi pupuk Walne yang berbeda. Penelitian ini menggunakan Rancangan Acak Lengkap (RAL) dengan tiga taraf perlakuan, yaitu $1 \mathrm{~mL} / \mathrm{L}, 1,5$ $\mathrm{mL} / \mathrm{L}$ dan $2 \mathrm{~mL} / \mathrm{L}$. Puncak kepadatan sel dari konsentrasi $1 \mathrm{~mL} / \mathrm{L}$ dan konsentrasi $1,5 \mathrm{~mL} / \mathrm{L}$ terjadi pada hari ke-9, dengan jumlah sel $259,25 \times 10^{4} \mathrm{sel} / \mathrm{mL}$ dan $323,50 \times 10^{4} \mathrm{sel} / \mathrm{mL}$, sedangkan konsentrasi $2 \mathrm{~mL} / \mathrm{L}$ mengalami puncak kepadatan pada hari ke-12 dengan jumlah sel 194,58 $\times 10^{4}$ $\mathrm{sel} / \mathrm{mL}$. Pemberian pupuk Walne $1,5 \mathrm{~mL} / \mathrm{L}$ menghasilkan nilai tertinggi untuk laju pertumbuhan spesifik dan klorofil-a $T$. chuii. Nilai laju pertumbuhan spesifik tertinggi adalah $0,38 \mathrm{sel} / \mathrm{mL} / \mathrm{hari}$ dengan kandungan klorofil-a $T$. chuii sebesar $2,392 \mathrm{mg} / \mathrm{g}$ biomassa basah. Hasil uji ANOVA dari data laju pertumbuhan spesifik dan kandungan klorofil-a menunjukkan bahwa tidak terdapat perbedaan signifikan $(p \geq 0,05)$. Konsentrasi yang bisa untuk meningkatkan laju pertumbuhan dan kandungan klorofil-a adalah konsentrasi 1,5 mL/L.
\end{abstract}

Kata kunci: Kepadatan Sel; Kultur Mikroalgae; Makronutrien; Mikronutrien

\section{Effect of Concentration of Walne Fertilizer on Growth Rate and Content of Chlorophyll-a Tetraselmis chuii}

ABSTRACT: Walne is a synthetic medium that is often used as a microalgae culture medium. Walne fertilizers already supply a complete nutritional needs for microalgae cultivation when compared to organic fertilizer. This study aims to determine the growth rate and content of chlorophyll-a microalgae Tetraselmis chuii in cultures with different concentrations of Walne fertilizer. The materials used were Tetraselmis chuii and Walne fertilizer obtained from Balai Besar Pengembangan Budidaya Air Payau (BBPBAP) Jepara. This research is using experimental laboratory method. The treatment given was to differentiate Walne fertilizer concentration. This study used a completely randomized design (RAL) three levels treatment, which is $1 \mathrm{~mL} / \mathrm{L}, 1.5 \mathrm{~mL} / \mathrm{L}$ and $2 \mathrm{~mL} / \mathrm{L}$. The peak of cell density from concentration $1 \mathrm{~mL} / \mathrm{L}$ and concentration $1.5 \mathrm{~mL} / \mathrm{L}$ occurred on day 9, with a cell number of $259.25 \times 104 \mathrm{cells} / \mathrm{mL}$ and $323.50 \times 104 \mathrm{cells} / \mathrm{mL}$, while concentration $2 \mathrm{~mL} / \mathrm{L}$ experienced a cell density peak on day 12 with a cell number of $194.58 \times 104$ cells $/ \mathrm{mL}$. The application of $1.5 \mathrm{~mL} / \mathrm{L}$ Walne fertilizer resulted in the highest values for the specific growth rate and chlorophyll-a of T. chuii. The highest specific growth rate value is $0.38 \mathrm{cell} / \mathrm{mL} /$ day with the chlorophyll-a content of T. chuii is $2.392 \mathrm{mg} / \mathrm{g}$ of wet biomass. The ANOVA test results from the growth rate and chloropyll-a content showed that there were no significant differences $(p \geq 0.05)$. The concentration that can increase the growth rate and chlorophyll-a content is a concentration of $1.5 \mathrm{~mL} / \mathrm{L}$.

Keywords: Cell Density; Microalgae Culture; Macronutrient; Micronutrient

\section{PENDAHULUAN}

Mikroalgae merupakan salah satu contoh organisme yang memiliki peran sangat luas dalam bidang bioteknologi. Aplikasi mikroalgae sebagai produk bioteknologi diantaranya adalah sebagai 
sumber biodiesel, agen remediasi perairan tercemar, dan pakan hewan budidaya (Schüler et al., 2020). Tetraselmis sp. merupakan mikroalgae yang tersebar luas, umum ditemukan, dan terdiri dari berbagai spesies. Satu atau lebih spesies dari genus ini dapat dengan mudah ditemukan pada setiap pengambilan sampel perairan (Butcher, 1965). Tetraselmis sp. memiliki potensi untuk dibudayakan sebagai pakan alami pada kegiatan budidaya (Iksan et al., 2016). Penggunan mikroalgae seperti Tetraselmis sp. sebagai pakan alami seringkali terkendala pada penyediaan dan pertumbuhan biomassanya. Kandungan pigmen tertinggi pada mikroalgae ini adalah klorofil dan karotenoid, dimana kedua pigmen tersebut dapat digunakan sebagai antioksidan, zat pewarna dan immunostimulan (Zainuddin et al., 2017; Pereira et al., 2019). Menurut Elmi (2018), diperlukan upaya penyediaan pakan alami yang baik dari segi kualitas maupun kuantitas. Ketersediaan mikroalgae secara terus menerus dan mudah untuk didapatkan sangat diperlukan untuk menunjang kegiatan budidaya. Salah satu spesies Tetraselmis yang banyak ditemukan di perairan tropis adalah Tetraselmis chuii. Pemenuhan kebutuhan Tetraselmis chuii dari alam akan sangat sulit apabila dilakukan secara terus menerus, sehingga harus dilakukan produksi massal secara baik. Ketersediaan Tetraselmis chuii dapat diperbanyak salah satunya dengan melakukan teknik kultur skala laboratorium (Setyawati et al., 2018).

Penggunaan media kultur dengan pupuk Walne dinilai lebih baik untuk meningkatkan pertumbuhan mikroalgae hijau dibandingkan dengan media Guillard karena kandungan nutrisinya yang lebih baik (Putri dan Alaa, 2019). Penggunaan pupuk sintesis seperti pupuk Walne untuk kultur mikroalga juga dinilai lebih praktis karena kandungan nutriennya yang sudah lengkap dibandingkan dengan pupuk organik (Budiono et al., 2018). Penelitian yang telah dilakukan oleh Wiryadi dan Witono (2018), dengan penambahan konsentrasi $\mathrm{NaNO}_{3}$ mengakibatkan pertumbuhan Nannochloropsis sp. yang semakin meningkat. Ezeani dan Abu (2019), melakukan penelitian terhadap pigmen Chlorella sp. dengan pupuk yang berbeda. Perbedaan pupuk yang diberikan dalam media kultur Chlorella sp. menghasilkan kadar klorofil yang berbeda hampir dua kali lipat. Berdasarkan latar belakang yang telah diuraikan, maka perlu dilakukan penelitian lebih lanjut mengenai laju pertumbuhan dan kadar klorofil-a pada mikroalga Tetraselmis chuii dengan perbedaan konsentrasi pupuk Walne dalam media kulturnya.

\section{MATERI DAN METODE}

Kultivasi mikroalga dilakukan pada tanggal 18 Februari - 08 April 2021 di Laboratorium Biologi Laut Fakultas Perikanan dan IImu Kelautan Universitas Diponegoro. Preparasi sampel ekstrak klorofil mikroalga dilakukan di Laboratorium Molekuler dan Laboratorium Biologi Laut Fakultas Perikanan dan IImu Kelautan Universitas Diponegoro pada tanggal 02 - 13 April 2021 dan pembacaan spektrofotometri dilakukan di Laboratorium Balai Pengujian dan Peralatan (BP2) Semarang pada tanggal 14 April 2021. Bibit mikroalgae Tetraselmis chuii dan pupuk Walne diperoleh dari Balai Besar Pengembangan Budidaya Air Payau (BBPBAP) Jepara. Alat yang digunakan untuk penelitian antara lain : botol kaca steril, aerator, mikroskop, $\mathrm{pH}$ meter, Refraktometer, pipet tetes, haemocytometer, sentrifuge dan spektrofotometer. Bahan yang digunakan untuk penelitian antara lain : air laut steril, bibit mikroalga Tetraselmis chuii, Akuades, Aseton, Lugol dan Kertas Whatmann. Metode yang digunakan dalam penelitian ini adalah metode percobaan di laboratorium (experimental laboratory), yang menggunakan Rancangan Acak Lengkap (RAL) perlakuan dengan tiga taraf perlakuan penelitian, dimana masing-masing taraf perlakuan diulang tiga kali. Taraf perlakuan tersebut berupa pemberian konsentrasi pupuk Walne 1 $\mathrm{mL} / \mathrm{L}, 1,5 \mathrm{~mL} / \mathrm{L}$ dan $2 \mathrm{~mL} / \mathrm{L}$. Penentuan konsentrasi pupuk didasarkan oleh penelitian Pramusinta et al. (2012), dimana penambahan pupuk cair sebagai nutrien tambahan memiliki batas optimal pada $1,5 \mathrm{~mL} / \mathrm{L}$. Data kepadatan sel dan data pendukung kualitas air berupa $\mathrm{pH}$, salinitas, oksigen terlarut dan suhu diukur setiap hari pukul 10.00 pagi.

Langkah awal untuk memulai kultur adalah sterilisasi alat dan bahan kultur yang dilakukan untuk membunuh mikroorganisme yang dapat menjadi kontaminan pada saat kultur mikroalgae. Sterilisasi botol kaca dilakukan dengan menggunakan Lampu UV dan alkohol 70\% (Ilhamdy et al., 2020). Air laut disetrilkan dengan cara disaring menggunakan kapas yang diletakkan pada corong air, kemudian air laut direbus selama kurang lebih 15 menit atau hingga mendidih. Air laut yang telah direbus kemudian dibiarkan hingga suhunya turun lalu disaring kembali dengan kapas filter. 
Peralatan kultur lainnya, seperti plastik, botol vial, pipet dan selang dapat disterilkan dengan alkohol $70 \%$ dengan cara menyemprotkan alkohol pada alat dan dibiarkan hingga kering (Putra et al., 2015).

Pembuatan media kultur menggunakan botol yang masing - masing berkapasitas 1 liter dan diisi air laut sebanyak kurang lebih $700 \mathrm{~mL} /$ botol yang sudah diukur salinitasnya sebesar 30 ppt. Media air laut ditambahkan pupuk dengan konsentrasi yang telah disesuaikan dan diberi aerasi (Zainuddin et al., 2017).

Bibit $T$. chuii terlebih dahulu dilakukan kultur starter yang bertujuan untuk memperpendek masa adaptasi mikroalgae pada media kultur yang lebih besar. Starter mikroalga $T$. chuii dibuat sebanyak 3 liter dalam 1 botol kultur yang berkapasitas 3,2 L. Pembuatan starter menggunakan perbandingan air laut : mikroagae sebesar $70: 30$. Setiap botol kultur yang telah berisi starter kemudian ditambahkan dengan pupuk Walne sebanyak $1 \mathrm{~mL} / \mathrm{L}$ sebagai sumber nutriennya dan diberi aerasi. Masa kultur starter dilakukan selama 7 hari atau sampai memasuki fase stasioner (Putra et al., 2015).

Kultur perlakuan $T$. chuii pada setiap wadah dibuat dengan perbandingan antara mikroalgae starter dengan air laut steril adalah $30: 70$, yaitu $300 \mathrm{~mL}$ inokulan mikroalgae dengan $700 \mathrm{~mL}$ media air laut. Kultur mikroalgae dilakukan selama kurang lebih 10 hari atau setelah mencapai fase stationer (Swandewi et al., 2017). Pupuk Walne dengan konsentrasi yang telah disesuaikan kemudian ditambahkan pada media kultur, masing - masing $1 \mathrm{~mL} / \mathrm{L} ; 1,5 \mathrm{~mL} / \mathrm{L}$; dan 2 $\mathrm{mL} / \mathrm{L}$. Masing - masing perlakuan konsentrasi dilakukan tiga kali pengulangan.

Perhitungan kepadatan sel mikroalgae $T$. chuii dilakukan sekali dalam 24 jam. Kepadatan sel dihitung menggunakan haemocytometer, mikroskop dan hand counter. Perbesaran mikroskop yang digunakan adalah 40x. Sampel diambil sebanyak 0,1-0,5 mL menggunakan pipet tetes, lalu ditambahkan larutan lugol sebanyak 2 tetes, selanjutnya diteteskan pada haemocytometer dan diamati dibawah mikroskop (Negara et al., 2019). Tujuan penambahan larutan lugol adalah untuk mengawetkan sampel dan memudahkan dalam perhitungan sel tanpa merusak sel mikroalga (Bimantara et al., 2017).

Perhitungan kepadatan sel mikroalgae dilakukan dengan menghitung sel mikroalgae yang terdapat pada empat blok besar (blok A, C, G, I) haemocytometer. Rumus yang digunakan untuk menghitung kepadatan sel mikroalgae adalah sebagai berikut (Endrawati et al., 2012). Data laju pertumbuhan dihitung menggunakan data kepadatan sel yang sudah didapat. Laju pertumbuhan spesifik sel mikroalgae dapat dihitung menggunakan rumus menurut Wahyuni et al. (2019).

Menurut Pisal dan Lele (2005), analisis pigmen klorofil-a dapat dilakukan dengan mengambil kultur basah mikroalga. Pengambilan ekstrak mikroalgae dilakukan dengan cara pemanenan menggunakan teknik sentrifugasi (Hartini et al., 2018). Biomassa mikroalgae sebanyak $500 \mathrm{~mL}$ diambil kemudian disentrifugasi dengan kecepatan $3500 \mathrm{rpm}$ selama 5 menit. Natan lalu diambil sebanyak $1 \mathrm{~mL}$ menggunakan pipet. Larutan aseton kemudian ditambahkan untuk mengencerkan filtrat dengan perbadingan $9: 1$ (9 $\mathrm{mL}$ aseton dan $1 \mathrm{~mL}$ natan). Sampel yang telah diencerkan dengan aseton kemudian dihomogenisasi. Setelah dihomogenkan, sampel di-sentrifugasi kembali dengan kecepatan $3500 \mathrm{rpm}$ selama 5 menit. Supernatan diambil dengan cara disaring menggunakan kertas whatmann no. 41. Menurut Nollet (2004), kadar klorofil dapat dilakukan dengan cara mengukur nilai absorbansi supernatan mikroalgae pada panjang gelombang $645 \mathrm{~nm}$ dan $663 \mathrm{~nm}$.

Data yang diperoleh dalam penelitian ini berupa data laju pertumbuhan dan kandungan klorofil-a dari mikroalgae $T$. chuii yang sudah diberi perlakuan beberapa konsentrasi pupuk Walne. Semua data akan dianalisis menggunakan Analysist of Variance (ANOVA) satu arah dengan menggunakan software SPSS 25 untuk mengetahui pengaruh perlakuan. Sebelum dilakukan uji ANOVA terlebih dahulu dilakukan uji normalitas dan homogenitas. Derajat kepercayaan yang digunakan sebesar 95\% atau dengan taraf signifikan sebesar 5\% (Jayardi et al., 2017). Data hasil penelitian kemudian dianalisis dengan statistika inferensial, dimana metode ini merupakan cara objektif untuk mengumpulkan, mengolah, dan menganalisis data kuantitatif untuk menarik kesimpulan (Sutopo dan Slamet, 2017). 


\section{HASIL DAN PEMBAHASAN}

Kepadatan awal sel Tetraselmis chuii yang dikultur adalah $33,5 \times 10^{4} \mathrm{sel} / \mathrm{mL}$, namun satu hari setelahnya ketiga perlakuan konsentrasi kultur mengalami penurunan jumlah sel. Menurut Negara et al. (2019), fase adaptasi mikroalga Tetraselmis chuii terjadi selama 1 - 3 hari. Fase adaptasi ini dapat dipengaruhi oleh ketersediaan nutrien pada media kultur. Semakin sedikit nutrien pada media, maka semakin lama masa adaptasi Tetraselmis chuii karena harus menyesuaikan nutrien yang ada. Pertumbuhan Tetraselmis chuii (Tabel 1) menunjukkan peningkatan jumlah sel pada hari ke-2 hingga hari ke-9 untuk perlakuan yang diberikan konsentrasi pupuk $1 \mathrm{~mL} / \mathrm{L}$ dan 1,5 mL/L, sedangkan peningkatan jumlah sel pada konsentrasi pupuk $2 \mathrm{~mL} / \mathrm{L}$ terjadi pada hari ke-2 hingga hari ke-12.

Putri et al. (2013), menyebutkan bahwa fase eksponensial mikroalga ditandai dengan adanya peningkatan jumlah sel mikroalga. Fase ini menunjukkan bahwa Tetraselmis chuii sudah dapat memanfaatkan nutrien yang ada untuk pertumbuhan dan pembelahan selnya. Puncak kepadatan perlakuan pupuk $1 \mathrm{~mL} / \mathrm{L}$ dan $1,5 \mathrm{~mL} / \mathrm{L}$ terjadi pada hari ke-9 dengan nilai kepadatan sel konsentrasi $1 \mathrm{~mL} / \mathrm{L} 259,25 \times 10^{4} \mathrm{sel} / \mathrm{mL}$ dan konsentrasi $1,5 \mathrm{~mL} / \mathrm{L} 323,50 \times 10^{4} \mathrm{sel} / \mathrm{mL}$, sedangkan perlakuan pupuk $2 \mathrm{~mL} / \mathrm{L}$ mengalami puncak kepadatan pada hari ke-12 dengan nilai $194,58 \times 10^{4} \mathrm{sel} / \mathrm{mL}$. Menurut Negara et al. (2019), fase stasioner merupakan fase dimana mikroalga mencapai puncak kepadatannya. Fase ini terjadi karena sel telah mencapai titik jenuh sehingga tingkat pertumbuhan sama dengan tingkat kematian selnya.

Pratiwi et al. (2019), menyebutkan bahwa pemberian nutrisi berlebih akan mengakibatkan kondisi stress pada mikroalgae budidaya dan berujung pada penurunan biomassa. Pertumbuhan mikroalga dipengaruhi oleh ketersediaan nutrisi pada media tumbuh yang terbagi menjadi makronutrien dan mikronutrien. Menurut Brahmantara et al. (2015), nitrat dan fosfor merupakan nutrient makro yang dibutuhkan untuk pertumbuhan sel mikroalga. Kandungan fosfor yang berlebih akan mempengaruhi pertumbuhan sel mikroalga. Kelebihan konsentrasi fosfor pada media tumbuh akan berdampak pada terhambatnya proses asimilasi senyawa fosfor untuk pertumbuhan mikroalga (Swandewi et al., 2017). Pertumbuhan mikroalgae dipengaruhi juga oleh ketersediaan mikronutrien dalam media tumbuhnya. Mikronutrien yang terkandung dalam pupuk Walne yang diberikan pada kultur Tetraselmis chuii antara lain Fe, Cu, Co, Zn dan Mn. Pranajaya et al. (2014), menyebutkan bahwa konsentrasi $\mathrm{Cu}$ yang berlebih dalam media dapat berakibat toksik bagi sel mikroalga dan menghambat pertumbuhan. Ion logam $\mathrm{Cu}$ dapat menganggu metabolisme mikroalgae karena Cu akan berkompetisi dengan senyawa lain pada sisi aktif enzim sehingga pertumbuhan mikroalgae menjadi rendah atau tidak tumbuh sama sekali.

Tabel 1. Kepadatan Sel Harian Tetraselmis chuii

\begin{tabular}{cccc}
\hline \multirow{2}{*}{ Hari ke - } & \multicolumn{3}{c}{ Kepadatan Sel Rata - Rata $\left(\times 10^{4} \mathrm{sel} / \mathrm{mL}\right)$} \\
\cline { 2 - 4 } & Kontrol & $1,5 \mathrm{ml} / \mathrm{L}$ & $2 \mathrm{ml} / \mathrm{L}$ \\
\hline 0 & $33,50 \pm 0$ & $33,50 \pm 0$ & $33,50 \pm 0$ \\
1 & $23,58 \pm 1,28$ & $14,83 \pm 2,25$ & $6 \pm 0,90$ \\
2 & $74,58 \pm 3,45$ & $52,83 \pm 7,84$ & $11,83 \pm 2,70$ \\
3 & $132 \pm 28,23$ & $111 \pm 7,51$ & $20,75 \pm 3,03$ \\
4 & $158,42 \pm 24,38$ & $148,67 \pm 36,97$ & $40,17 \pm 17,95$ \\
5 & $162,08 \pm 29,04$ & $165,50 \pm 5,86$ & $57,17 \pm 36,46$ \\
6 & $215,17 \pm 87,35$ & $196,17 \pm 29,77$ & $85,42 \pm 36,28$ \\
7 & $184,58 \pm 55,81$ & $220,08 \pm 29,17$ & $108 \pm 43,05$ \\
8 & $248,50 \pm 89,79$ & $223,67 \pm 40,88$ & $121,92 \pm 47,82$ \\
9 & $259,25 \pm 121,62$ & $323,50 \pm 69,74$ & $119,25 \pm 80,89$ \\
10 & $238,50 \pm 93,74$ & $317,42 \pm 55,02$ & $112,08 \pm 72,50$ \\
11 & $242,42 \pm 57,07$ & $301,67 \pm 51,84$ & $167,92 \pm 69,88$ \\
12 & $215,42 \pm 41,21$ & $283,50 \pm 111,71$ & $194,58 \pm 63,75$ \\
13 & $189,08 \pm 48,92$ & $226,42 \pm 45,31$ & $178,17 \pm 65,75$ \\
\hline
\end{tabular}


Nilai laju pertumbuhan spesifik rata-rata sel mikroalga Tetraselmis chuii disajikan dalam Tabel 2. Nilai laju pertumbuhan spesifik tertinggi ada pada konsentrasi pupuk $1,5 \mathrm{~mL} / \mathrm{L}$, yaitu sebesar $0,38 \mathrm{sel} / \mathrm{mL} /$ hari. Laju pertumbuhan spesifik pada konsentrasi $2 \mathrm{~mL} / \mathrm{L}$ memiliki nilai 0,36 $\mathrm{sel} / \mathrm{mL} /$ hari, sedangkan pada konsentrasi $1 \mathrm{~mL} / \mathrm{L}$ memiliki nilai laju pertumbuhan spesifik sebesar $0,29 \mathrm{sel} / \mathrm{mL} / \mathrm{hari}$.

Laju pertumbuhan $T$. chuii yang diberikan pupuk Walne dengan konsentrasi $1,5 \mathrm{~mL} / \mathrm{L}$ memiliki nilai paling tinggi diantara taraf perlakuan lainnya. Tetraselmis chuii yang diberikan pupuk $1 \mathrm{~mL} / \mathrm{L}$ memiliki nilai laju pertumbuhan terendah dibanding taraf perlakuan lainnya. Berdasarkan Wahyuni et al. 2019), nilai laju pertumbuhan yang rendah dapat disebabkan karena kandungan nitrogen dan fosfat terlarut yang tidak dapat diserap dengan baik oleh sel mikroalga. Aulia et al. (2021), menyatakan bahwa nilai laju pertumbuhan spesifik yang semakin tinggi menunjukkan bahwa daya dukung media terhadap mikroalgae semakin baik. Menurut Oktaviani et al. (2017), semakin tinggi kadar nitrat pada media kultur, maka akan semakin tinggi pula nilai laju pertumbuhan mikroalgae. Hal ini disebabkan karena nitrat merupakan makronutrien penting yang digunakan untuk pembentukan klorofil, sehingga suplai nitrat yang tinggi akan berakibat pada pembelahan sel dan fotosintesis yang lebih tinggi.

Kandungan rata - rata klorofil-a pada mikroalga Tetraselmis chuii (Gambar 3) menunjukan nilai tertinggi hingga terendah pada konsentrasi pupuk $1,5 \mathrm{~mL} / \mathrm{L} ; 1 \mathrm{~mL} / \mathrm{L}$; dan $2 \mathrm{~mL} / \mathrm{L}$, yaitu berturut - turut sebesar 248,81 mg/L; 165,33 mg/L; dan 145,02 mg/L. Nilai klorofil-a yang diubah menjadi satuan miligram / gram biomassa basah pada perlakuan $1,5 \mathrm{~mL} / \mathrm{L} ; 1 \mathrm{~mL} / \mathrm{L}$; dan $2 \mathrm{~mL} / \mathrm{L}$ adalah 2,3924 mg/g biomassa basah; 1,6370 mg/g biomassa basah; dan 1,4217 mg/g biomassa basah. Qaishum et al. (2015), menyatakan bahwa kandungan total klorofil pada Tetraselmis chuii berkisar antara 3,65 - 19,20 $\mathrm{mg} / \mathrm{g}$.

Tabel 2. Laju Pertumbuhan Spesifik Rata- Rata Tetraselmis chuii $(\bar{x} \pm S D, n=3)$

\begin{tabular}{cccc}
\hline $\begin{array}{c}\text { Konsentrasi/ } \\
\text { Ulangan }\end{array}$ & $1 \mathrm{~mL} / \mathrm{L}$ & $1,5 \mathrm{~mL} / \mathrm{L}$ & $2 \mathrm{~mL} / \mathrm{L}$ \\
\hline 1 & 0,34 & 0,40 & 0,32 \\
2 & 0,29 & 0,41 & 0,28 \\
3 & 0,24 & 0,34 & 0,46 \\
\hline Rerata \pm SD & $0,29 \pm 0,05$ & $0,38 \pm 0,04$ & $0,36 \pm 0,09$ \\
\hline
\end{tabular}

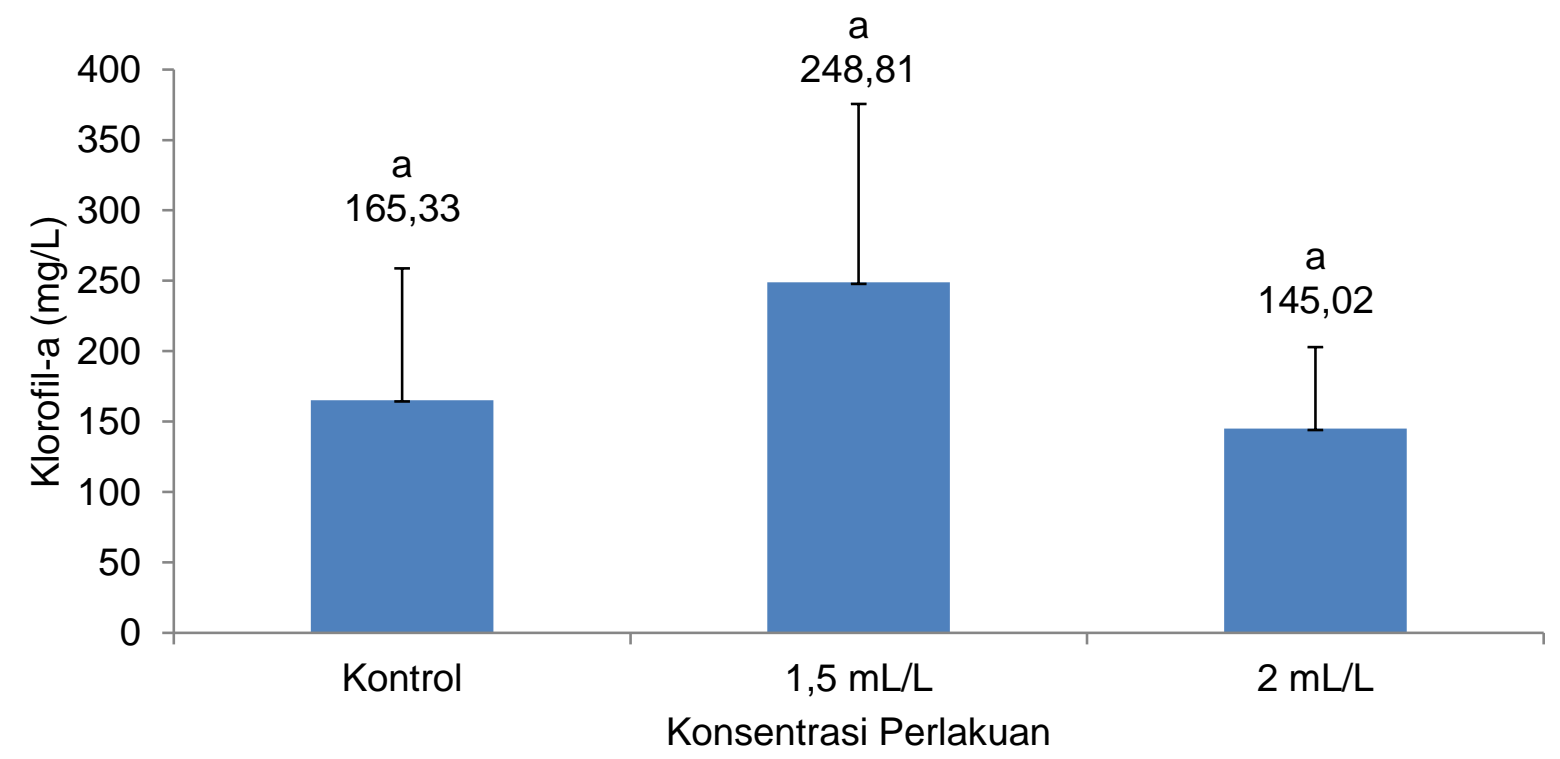

Gambar 1. Kandungan Klorofil-a Tetraselmis chuii (mg/L) 
Keterangan : Angka dengan huruf yang sama menunjukkan tidak ada perbedaan nyata berdasarkan uji ANOVA pada taraf $5 \%(p \geq 0,05)$

Apabila kandungan klorofil-a (Gambar 1) dikaitkan dengan kepadatan sel Tetraselmis chuii (Tabel 1), maka laju petumbuhan sel sebanding dengan kadar klorofil-a yang didapat. Menurut Oktaviani et al. (2017), jumlah biomassa mikroalgae berkaitan dengan proses fotosintesis oleh klorofil dan sintesis klorofil-a dapat berlangsung dengan baik apabila ketersediaan $\mathrm{N}$ dalam media sudah cukup sesuai. Nitrogen dibutuhkan sebagai elemen penyusun klorofil dan protein pada sel mikroalga. Semakin tinggi kadar nitrat maka semakin tinggi biomassa dan klorofil-a yang dihasilkan.

Konsentrasi unsur mikro yang berbeda dalam pupuk juga akan mempengaruhi proses pembuatan klorofil. Menurut Apriati (2021), unsur yang berperan penting dalam pembentukan klorofil pada mikroalgae adalah $\mathrm{Fe}$ dan $\mathrm{Mg}$. semakin tinggi kandungan $\mathrm{Fe}$ dan $\mathrm{Mg}$ dalam suatu media, maka semakin tinggi pula kadar klorofil yang dihasilkan. Berdasarkan Pratiwi et al. (2019), magnesium memiliki peranan fisiologis bagi tanaman karena merupakan komponen utama dalam molekul klorofil. Setidaknya 15-30\% magnesium yang terdapat pada tanaman tergabung dalam molekul klorofil. Menurut Primaryadi et al. (2015), Magnesium (Mg) berperan dalam pembentukan klorofil pada proses pertumbuhan mikroalgae. Selain itu Mg juga mengatur penyerapan unsur lain seperti P dan K.

Pengukuran parameter media kultur Tetraselmis chuii dilakukan setiap hari meliputi pengukuran suhu, salinitas, $\mathrm{pH}$ dan $\mathrm{DO}$. Suhu media kultur pada ketiga perlakuan berkisar antara $18,5^{\circ}-21^{\circ} \mathrm{C}$, salinitas berkisar antara $28-34$ ppt, nilai pH antara 7,05-8,69 dan nilai DO antara 5,87,5 mg/l (Tabel 3).

Adanya kenaikan suhu pada masa kultur berakibat pada menurunnya kepadatan sel konsentrasi $1 \mathrm{~mL} / \mathrm{L}$ dan $1,5 \mathrm{~mL} / \mathrm{L}$. Kultur $T$. chuii pada konsentrasi $2 \mathrm{~mL} / \mathrm{L}$ mengalami kenaikan suhu menjadi $20^{\circ} \mathrm{C}$ pada hari ke-10 dan seterusnya, dimana kepadatannya mulai mengalami penurunan setelah hari ke-12 dan seterusnya. Hal ini sesuai dengan Endrawati dan Ita (2013), bahwa kondisi suhu akan berpengaruh pada laju fotosintesis sel microalgae. Gas - gas seperti $\mathrm{O}_{2}$ dan $\mathrm{CO}_{2}$ yang digunakan dalam proses fotosintesis lebih mudah terlaruh dalam suhu yang rendah, akibatnya laju fotosintesis akan meningkat pada suhu yang rendah.

Apabila nilai $\mathrm{pH}$ kultur $T$. chuii dikaitkan dengan nilai kepadatan selnya maka sejalan dengan naiknya nilai $\mathrm{pH}$, kepatadan sel $T$. chuii juga ikut meningkat. Hal ini sesuai dengan Sayadi et al. (2016), bahwa nilai pH bertambah sesuai dengan bertambahnya jumlah sel mikroalga dan naiknya kadar nitrat dan fosfat pada media. Kenaikan nilai pH disebabkan karena adanya pengendapan fosfat pada media kultur.

Salinitas awal kultur Tetraselmis chuii adalah 30 ppt, namun terjadi penurunan maupun kenaikan selama masa kultur. Rata - rata salinitas media kultur masih ada dalam batas toleransi pertumbuhan Tetraselmis chuii. Berdasarkan Fitriyanto dan Soeprobowati (2013), nilai salinitas secara alami dapat mengalami peningkatan karena respirasi dari organisme dalam air akan meningkatkan proses mineralisasi yang menyebabkan kadar garam meningkat.

Tabel 3. Parameter Media Kultur

\begin{tabular}{cccccc}
\hline \multirow{2}{*}{$\begin{array}{c}\text { Konsentarasi/ } \\
\text { Ulangan }\end{array}$} & \multicolumn{4}{c}{ Kisaran hasil pengukuran } \\
\cline { 2 - 6 } & 1 & Suhu $\left({ }^{\circ} \mathrm{C}\right)$ & Salinitas $(\mathrm{ppt})$ & $\mathrm{pH}$ & $\mathrm{DO}(\mathrm{mg} / \mathrm{l})$ \\
\hline \multirow{2}{*}{$1 \mathrm{~mL} / \mathrm{L}$} & 2 & $19-21$ & $28-32$ & $7,05-7,99$ & $6,1-7$ \\
$($ Kontrol) & 3 & $19-20,5$ & $27-30$ & $7,29-7,99$ & $5,9-6,6$ \\
& 1 & $19-20$ & $27-31$ & $7,46-8,69$ & $6,2-7,1$ \\
& 1 & $28-30$ & $7,29-8,32$ & $6,2-6,9$ \\
$1,5 \mathrm{~mL} / \mathrm{L}$ & 2 & $19-20$ & $29-31$ & $7,33-8,68$ & $6,2-6,9$ \\
& 3 & $19-21$ & $29-31$ & $7,12-8,39$ & $6,3-6,8$ \\
$2 \mathrm{~mL} / \mathrm{L}$ & 1 & $18,5-20,5$ & $30-34$ & $7,13-8,36$ & $5,8-7,5$ \\
\hline
\end{tabular}


Journal of Marine Research Vol 11, No.1 Februari 2022, pp. 77-85

$\begin{array}{lllll}2 & 18,5-20 & 30-34 & 7,12-7,97 & 5,7-6,5 \\ 3 & 19-20,5 & 30-34 & 7,07-8,66 & 6,1-6,8\end{array}$

Ketersediaan oksigen terlarut pada media kultur berpengaruh terhadap pembentukan molekul organik melalui proses fotosintesis. Kandungan oksigen terlarut untuk pertumbuhan mikroalgae memiliki nilai optimal antara 4,65 - 6,27 mg/l (Maulana et al., 2017). Nilai oksigen terlarut yang diukur pada masa awal kultur untuk ketiga taraf perlakuan bernilai antara 6,8 -7 $\mathrm{mg} / \mathrm{L}$. Pengukuran oksigen terlarut selama masa kultur selanjutnya menunjukkan nilai yang lebih rendah, dimana nilai oksigen terlarut berbanding terbalik dengan nilai suhu. Ketika suhu kultur mengalami peningkatan maka nilai oksigen terlarut yang terukur akan mengalami penurunan. Nilai oksigen terlarut yang turun menandakan bahwa proses fotosisntesis tidak lancar (Nurhayati et al., 2013).

\section{KESIMPULAN}

Perbedaan konsentrasi pupuk Walne tidak berpengaruh nyata terhadap peningkatan laju pertumbuhan $(p=0,280)$ dan kandungan klorofil-a $(p=0,463)$ mikroalga Tetraselmis chuii. Namun demikian konsentrasi pupuk Walne $1,5 \mathrm{~mL} / \mathrm{L}$ dapat meningkatkan laju pertumbuhan dan kandungan klorofil-a Tetraselmis chuii sebesar 0,38 sel/ml/hari dan 248,81 mg/L atau 2,392 mg/g biomassa basah.

\section{DAFTAR PUSTAKA}

Apriati, D. 2021. Kadar Klorofil Chlorella pyrenoidosa dalam Berbagai Konsentrasi Limbah Cair Tahu. UNBARA Environmental Engineering Journal, 01(02):1-8

Aulia, A.E., Maimunah, Y. \& Suprastyani, H. 2021. Penggunaan Ekstrak Daun Lamtoro (Leucaena Leucocephala) sebagai Pupuk dengan Salinitas yang Berbeda terhadap Laju. Journal of Fisheries and Marine Research, 5(1):47-55.

Bimantara, A., Santri, D.J. \& Susanti, R. 2017. Pengaruh Pupuk Cair Anorganik terhadap Kepadatan Fitoplankton dan Sumbangannya pada Pembelajaran Biologi di Prosiding Seminar Nasional Pendidikan IPA, pp. 415-427.

Brahmantara, I.B.G., Anggreni, A.A.M.D. \& Gunam, I.B.W. 2015. Pengaruh Konsentrasi Penambahan Sodium Nitrat dan Sodium Fosfat pada Media Guillard terhadap Konsentrasi Biomassa Mikroalga Nannochloropsis sp. Jurnal Rekayasa dan Manajemen Agroindustri, 3(4):73-81.

Budiono, R., Juahir, H. \& Mamat, M. 2018. Modelling Interaction of $\mathrm{CO}_{2}$ Concentration and the Biomass Algae Due to Reduction of Anthropogenic Carbon Based on Predator-Prey Model. International Journal of Applied Environmental Sciences, 13(1):27-38.

Butcher, R.W. 1965. An Introductory Account of the Smaller Algae of British Coastal Waters. Part V. Bacillariophyceae (Diatoms). London: Ministry of Agriculture, Fisheries and Food. DOI : $10.2307 / 2258001$.

Ezeani, S. \& Abu, O.G. 2019. Commercial Microalgae Culture in Inorganic Fertilizer Media. Current Journal of Applied Science and Technology, 38(4):1-9. DOI: 10.9734/cjast/2019/v38i430372.

Elmi, D. 2018. Pengaruh Pemberian Darah lkan Tongkol (Euthynnus affinis) dengan Dosis yang Berbeda terhadap Laju Pertumbuhan dan Kepadatan Populasi Infusoria The Effect of Blood Tuna Fish (Euthynnus affinis) With Different Doses on the Growth Rate and Population Den, Jurnal IImiah Mahasiswa Kelautan dan Perikanan Unsyiah, 3(1):33-38.

Endrawati, H., Manulang, C. \& Widianingsih, 2012. Densitas dan Kadar Total Lipid Mikroalga Spirulina platensis yang Dikultur pada Fotoperioda yang Berbeda. Buletin Oseanografi Marina, 1(3):33-38. DOI: 10.14710/buloma.v1i3.6908.

Endrawati, H. \& Ita, R. 2013. Kadar Total Lipid Mikroalga Nannochloropsis oculata yang Dikultur dengan Suhu yang Berbeda. Buletin Oseanografi Marina, 2(1): 25-33. DOI: 10.14710/buloma.v2i1.6923.

Fitriyanto, E.B. \& Soeprobowati, T.R. 2013. Pemanfaatan Plasma Lucutan Pijar Korona sebagai Sumber Nutrien Alternatif pada Monokultur Dunaliella salina (Dunal), Prosiding Seminar 
Nasional Biologi, 1:277-279.

Hartini, H., Lasmini, T, Pratiwi, M. \& Juita, E. 2018. Potensi Biopigmen Chlorella sp. sebagai Antibakteri Staphilococcus aureus. Jurnal Sains dan Teknologi Laboratorium Medik, 3(1):1-7.

Iksan, Junaidi, M. \& Mukhlis, A. 2016. Pengaruh Pemberian Ragi Roti dengan Dosis yang Berbeda terhadap Pertumbuhan Populasi Brachionus Plicatilis. Jurnal Biologi Tropis, 16(1):1-9. DOI: 10.29303/jbt.v16i1.218.

Ilhamdy, A.F., Jumsurizal, Darwin, \& Tambunan, Y.F.S. 2020. Kultivasi Spirulina platensis Menggunakan Media Walne dalam Skala Laboratorium. Marinade, 3(2):114-120.

Jayardi, A., Irawan, H. \& Julianto, T. 2017. Pengaruh Pemberian Fitoplankton(Tetraselmis Chuiii, Tetraselmis Suecica dan Nanochloropsis Oculata) yang Berbeda terhadap Pertumbuhan Kopepoda Apocyclops sp. Intek Akuakultur, 1(2): 23-42.

Maulana, P.M., Karina, S. \& Mellisa, S. 2017. Pemanfaatan Fermentasi Limbah Cair Tahu Menggunakan Em4 sebagai Alternatif Nutrisi bagi Mikroalga Spirulina sp. Jurnal IImiah Mahasiswa Kelautan dan Perikanan Unsyiah, 2(1):104-112.

Negara, B.F.S.P., Nursalim, N., Herliany, N.E., Renta, P.P., Purnama, D. \& Utami, M.A.F. 2019. Peranan dan Pemanfaatan Mikroalga Tetraselmis chuii sebagai Bioetanol, Jurnal Enggano, 4(2):136-147.

Nollet, L.M. 2004. Handbook of Food Analysis: Volume 1: Physical Characterization and Nutrient Analysis. CRC Press, United States.

Nurhayati, T., Mustofa, L. \& Mochammad, B.H. 2013. Penggunaan Fotobioreaktor Sistem Batch Tersirkulasi terhadap Tingkat Pertumbuhan Mikroalga Chlorella vulgaris, Chlorella sp . dan Nannochloropsis oculata, Jurnal Keteknikan Pertanian Tropis dan Biosistem, 1(3): 249-257.

Oktaviani, D., Adisyahputra \& Amelia, N. 2017, Pengaruh Kadar Nitrat terhadap Pertumbuhan dan Kadar Lipid Mikroalga Melosira sp. sebagai Tahap Awal Produksi Biofuel, Jurnal Risenologi KPM UNJ, 2(1): 1-13.

Pereira, H., Silva, J., Santos, T., Gangadhar, K.N., Raposo, A., Nunes, C., Coimba, M.A., Gouveia, L., Barreira, L. \& Varela, J. 2019. Nutritional Potential and Toxicological Evaluation of Tetraselmis sp. CTP4 Microalgal Biomass Produced in Industrial Photobioreactors. Molecules, 24(17):1-18. DOI: 10.3390/molecules24173192.

Pisal, D.S. \& Lele, S.S. 2005. Carotenoid Production from Microalga, Dunaliella salina. Indian Journal of Biotechnology, 4(4):476-483.

Pramusinta, G., Masithah, E.D., \& Rahardja, B.S. 2012. Pengaruh Pemberian Pupuk Cair Limbah Ikan Lemuru terhadap Kandungan Karotenoid Spirulina platensis. Journal of Marine and Coastal Science, 1(1):91-100.

Pranajaya, R.H., Ali, D, \& Bambang, Y. 2014. Pengaruh Tembaga terhadap Kandungan Pigmen dan Pertumbuhan Mikroalga Merah Porphyridium cruentum. IImu Kelautan, 19(2):97-104.

Pratiwi, A., Rohmat \& Purba, E. 2019, Penentuan Jumlah Nutrisi Magnesium dari $\mathrm{MgSO}_{4} .7 \mathrm{H}_{2} \mathrm{O}$ dan Besi dari $\mathrm{FeSO}_{4} .7 \mathrm{H}_{2} \mathrm{O}$ pada Kultivasi Tetraselmis chuii terhadap Kandungan Lipid Maksimum. Jurnal Kelitbangan, 7(1):75-86.

Primaryadi, I.N.B., Anggreni, A.A.M.D. \& Wartini, N.M. 2015. Pengaruh Penambahan Magnesium Sulfat Heptahidrat dan Feri Klorida pada Blue Green Medium-11 terhadap Konsentrasi Biomassa Mikroalga Tetraselmis chuii. Jurnal Rekayasa dan Manajemen Agroindustri, 3(2): 92-100.

Putra, I.K.R.W., Anggreni, A.A.M.D. \& Arnata, I.W. 2015. Pengaruh Jenis Media terhadap Konsentrasi Biomassa dan Klorofil Mikroalga Tetraselmis chuii. Jurnal Rekayasa, 3(2):40-46.

Putri, B., Vickry, A.H., \& Maharani, H.W. 2013. Pemanfaatan Air Kelapa sebagai Pengkaya Media. Prosiding Seminar FMIPA Universitas Lampung, pp. 135-142.

Putri, D.S. \& Alaa, S. 2019. The Growth Comparison of Haematococcus pluvialis in Two Different Medium. Biota, 12(2):90-97. DOI: 10.20414/jb.v12i2.202.

Qaishum, F., Amun, A. \& Syelvia, P.U. 2015. Hidrolisis Mikroalga Tetraselmis chuii Menjadi Glukosa Menggunakan Solvent $\mathrm{H}_{2} \mathrm{SO}_{4}$ dengan Variasi Waktu Hidrolisis, Jom Fteknik, 2(1):1-5.

Sayadi, M.H., Ahmadpour, N., Capoorchali, M.F. \& Rezaei, M.R. 2016. Removal of Nitrate and Phosphate from Aqueous Solutions by Microalgae: An experimental study. Global Journal of Environmental Science and Management, 2(4): 357-364. DOI: 10.22034/gjesm.2016.02.04.005. 
Schüler, L.M., Santos, T., Pereira, H., Duarte. P.,Gangadhar, K.N., Floroindo, C., Schulze, P.S.C., Barreira, L. \& Varela, J.C.S. 2020. Improved Production of Lutein and $\beta$-carotene by Thermal and Light Intensity Upsift in the Marine Microalga Tetraselmis sp. CTP4', Algal Research, 45: 1-9. DOI: 10.1016/j.algal.2019.101732.

Setyawati, F., Satyantini, W.H., Arief, M. \& Kismiyati, 2018. Tenik Kultur Tetraselmis chuii dalam Skala Laboratorium DI PT. Central Pertiwi Bahari, Rembang, Jawa Tengah. Journal of Aquaculture and Fish Health, 7(2):63-69. DOI: 10.20473/jafh.v7i2.11249.

Sutopo, E.Y., \& Slamet, A. 2017. Statistik Inferensial, Penerbit Andi,Yogyakarta.

Swandewi, I.G.A.P.A.P., Anggreni, A.A.M.D. \& Ahmadi, B. 2017. Pengaruh Penambahan $\mathrm{NaNO}_{3}$ dan $\mathrm{K}_{2} \mathrm{HPO}_{4}$ pada Media BG-11 terhadap Konsentrasi Biomassa dan Klorofil Tetraselmis chuii. Jurnal Rekayasa, 5(1):1-11.

Wahyuni, N., Rahardja, B.S. \& Azhar, H. 2019, Pengaruh Pemberian Kombinasi Konsentrasi Ekstrak Daun Kelor (Moringa oleifera) dengan Pupuk Walne dalam Media Kultur terhadap Laju Pertumbuhan dan Kandungan Karotenoid Dunaliella salina. Journal of Aquaculture Science, 4(1):37-49.

Wiryadi, F. \& Witono, J.R.B. 2018, Pengaruh Aerasi dan Penambahan Nitrogen terhadap Laju Pertumbuhan Nannochloropsis sp., Prosiding Seminar Nasional Teknik Kimia "Kejuangan" , Yogyakarta 12 April 2018, pp. 1-6.

Zainuddin, M., Hamid, N., Mudiarti, L., Kursistyanto, N. \& Aryono, B. 2017, Pengaruh Media Hiposalin dan Hipersalin terhadap Respon Pertumbuhan dan Biopigmen Dunaliella salina, Jurnal Enggano, 2(1):46-57. DOI: 10.31186/jenggano.2.1.46-57. 